\title{
The Influence of Brand Image and Celebrity Endorsement in Purchase Intention of Adolescent Girls Using Instagram.
}

\author{
Budi Santoso* \\ budi_santoso@staff.gunadarma.ac.id \\ Gunadarma University, Jl. Margonda Raya 100 Depok, 16424, Indonesia
}

\begin{abstract}
.
Companies can use marketing strategies to attract consumers' purchase intentions. The strategies carried out by the company include through, products, brands or using celebrity endorsements. This study uses a $2 \times 2$ factorial design, which consists of two independent variables, namely the image of well-known and unknown brands as well as famous and unknown celebrity endorsements and one dependent variable, namely purchase intention. The research object was 100 female students who were randomly divided into 4 groups with the same number of samples in each group. Data were analyzed by Two Way ANOVA method. The results showed that there were differences in purchase intentions based on the image of well-known and unknown brands on Instagram social media users. Adolescent girls have a higher purchase intention on a well-known brand image than an unknown brand image, as well as a higher purchase intention if they use a well-known celebrity endorsement compared to an unknown celebrity endorsement. There is no interaction of brand image with celebrity endorsement, in determining purchase intention of adolescent girls using Instagram social media.
\end{abstract}

Keywords: Purchase intention, famous and unknown brand image, famous and unknown celebrity endorsement, advertisement.

\section{Introduction}

Companies can use marketing strategies to attract consumers' purchase intentions. Marketing strategies carried out by the company through products, brands or using celebrity endorsements. In an effort to predict or influence changes in consumer behavior, intention is one important element and is considered a close proxy for the behavior itself (Balau, 2018).

Purchase intention is often measured and used by marketing managers as input for decisions about new and existing products and services. Intentions are often used as input for future sales or new product sales projections based on product concepts or testing (Morwitz, 2014)

Intention to buy online is based on the relationship between behavioral intention and actual behavior. The individual's behavioral intention to take action will determine the actual individual behavior. Thus, purchase intention is a factor that predicts the actual behavior or purchasing decisions of customers (Kim \& Rao, 2008).

Brands currently play a number of important roles that improve the lives of consumers and increase the company's financial value (Oladepo, 2015). Good quality brands can foster consumer buying interest in a product (Kotler, 2008).

The use of celebrity endorsement is an interesting method in the world of advertising, using the right celebrity will be able to make the product being promoted to be known to the public, known and in demand. Celebrity endorsement is one of the advertising techniques used by companies to create awareness and get favorable responses about their products and services (Apejoye, 2013) Celebrity endorsement has become one of the important tools in advertising that persuades customers, using celebrity endorsements with high credibility can help consumers to remember brands and can influence them to remember when they are in store purchases (Ahmed, 2014)

Celebrity endorsements have become a popular choice in advertising because the originality and attractiveness of celebrities make a huge impact on brand awareness and customer behavior (Ha \& Lam, 2017). Advertisements on social media that use consumer endorsers can be an effective channel in reaching out to inform and educate consumers about products or services (Predanorawut, 2011)

Celebrity endorsement has a significant relationship with purchase intention (Younus, 2015) (Min, 2019) celebrity brand suitability and publicity play an important role in consumer behavior related to attitudes towards 
celebrities and brands or products, as well as purchase intentions. (Ateke, 2015) suggests a strong and positive correlation between celebrity endorsement and brand awareness.

According to (Alhadad, 2015) social media is a phenomenon that has attracted a lot of attention both for companies and individuals interacting in the network landscape. Internet advertising has taken new forms that have an advantage over traditional media such as print, TV and radio. Social media is a good medium for advertising, despite the challenges inherent in its use (Nyekwere, 2013). According to (Farhangi, 2014) social media is now one of the most important sources of information from customers. One of the social media that is growing very rapidly today is Instagram social media.

\section{Research Method}

The purpose of this study is to test and analyze:

1. Differences in purchase intention based on the image of well-known and unknown brands on young girls using Instagram social media.

2. Differences in purchase intentions based on well-known and unknown celebrity endorsements in young women using Instagram social media.

3. Interaction of brand image with celebrity endorsement in determining purchase intention of adolescent girls using Instagram social media.

Participants who took part in the experimental stage were 100 female students using Instagram with ages between 18 -23 years from several faculties. The distribution of participants by faculty can be seen in Table 1 .

Table 1. Distribution of Participants by Faculty

\begin{tabular}{clc}
\hline No. & \multicolumn{1}{c}{ Faculty } & Amount \\
\hline 1 & Communication Studies & 78 \\
2 & Economy & 12 \\
3 & Psychology & 6 \\
4 & Industrial Engineering & 4 \\
& To t a l & 100 \\
\hline
\end{tabular}

The experimental data collection technique is as follows, distributing questionnaires to 100 respondents using google form to test the measuring instrument that will be used for experimental testing. After measuring all the item discrimination power values are good, it will be continued with the experimental test. An explanation to participants about the background of the research and the experimental process that will be carried out through a video conference platform, namely google meet.

Participants in each group were 25 female students. Questionnaires in the form of google form for each experimental group were distributed to each participant. Before the participants filled out the questionnaire, the stimulus contained in each questionnaire in each experimental group was explained first. The data obtained in the experiment were analyzed using two-factor analysis of variance (Two Way ANOVA).

The use of Two-Factor ANOVA must meet several reasons. The first reason to use Two-Factor ANOVA is because the dependent variable is one, namely purchase intention and there are two independent variables, where each independent variable has two groups, namely brand image (famous and unknown) and celebrity endorsement (famous and unknown).

\section{Results and Discussion}

Hypothesis testing is carried out to determine whether or not the hypothesis proposed in the study is accepted. The basis for decision making in the Two Way Anova test is if the value of Sig. $<0.05$, then there is a difference in purchase intention based on the factor variable. Based on the results of hypothesis testing, the value of Sig. of each factor variable as follows:

1. Sig. brand image of $0.010<$ (smaller) than 0.05 , which means that there is a difference in purchase intention based on the image of well-known and unknown brands on Instagram social media users.

2. Sig. celebrity endorsement is $0.015<$ (smaller) than 0.05 , which means that there is a difference in purchase intention based on well-known and unknown celebrity endorsements on Instagram social media users. 
3. Sig. brand image with celebrity endorsement is $0.251>$ (larger) than 0.05 , which means that there is no interaction between brand image and celebrity endorsement in determining purchase intention on Instagram social media users. The results of the hypothesis can be seen in table 2 .

Table 2. Hypothesis Test Results

\begin{tabular}{lcc}
\hline \multicolumn{1}{c}{ Source } & F & sig \\
\hline Brand & 6,974 & 0,010 \\
Celebrity & 6,130 & 0,015 \\
Brand * Celebrity & 1,335 & 0,251 \\
\hline
\end{tabular}

Source: Primary data processed by SPSS 26

According to (Aaker, 2018) audiences tend to buy familiar brands because they feel safe with something known, or there may be an assumption that a known brand has the possibility of reliability, stability in business, and quality that can be accounted for. The awareness factor is especially important in a context where the brand must first enter the series of considerations, definitely one of the brands being evaluated. Unknown brands usually have little chance. In line with his research (Sulu, 2016) Consumers prefer to buy products from well-known brands. Young people prefer to buy brands that represent or have a personality similar to them or that suit their lifestyle. Young people looking for trendy/spirited, successful and genuine brands seem at their age, they don't want to see themselves reflected in brands that are domestic/emotional or professional. The more genuine, sophisticated, trendy, and robust brands, and the less domestic and professional, the greater the purchase intention (De la Paz, 2015). Brand components will have a significant effect on consumer perceptions and consumers will prefer brands that have branded components (Raza, 2013). Consumers will prefer to buy brands they know well (Shahid, 2017). The greater the perceived luxury value of the brand among consumers, the greater their brand attachment, which in turn leads to greater purchase intention (Petraviciute, 2021).

In accordance with the theory of attitude and attitude change (Aronson, 2007) that the effectiveness of persuasive communication depends on "Who says what to whom" where; Who (the source of communication) in this study is a celebrity endorsement, the more famous the celebrity endorsement, the more effective it will be to influence purchase intentions. To Whom (Audience) in this study the audience is student Instagram users, if the student gets a good source of communication, namely a known celebrity endorsement, it will affect the purchase intention quite large.

It can be concluded that brand image and celebrity endorsement do not influence each other or have no effect on each other. It could be that consumers intend to buy a product because the consumer is loyal to a brand because it has a good brand image, without paying attention to other factors, such as celebrity endorsement. In line with the theory of (Aaker, 2018), that brand loyalty from customer groups is often the core of brand equity. Customers continue to buy the brand, even when faced with competitors who offer superior product characteristics in terms of price and practicality, which means that there is immense value in the brand and perhaps also in its symbols and slogans.

It could also be that consumers intend to buy a product because celebrity endorsements are used as their idol figures without paying attention to other factors, such as brands. In line with his research (Adyatami, 2015), that the credibility of celebrity endorsement sources has no significant effect on consumer attitudes towards brands. There is no influence of celebrity endorsement on brand image (Tariq, 2018). A brand that is viewed positively does not necessarily increase the same attributes of attractiveness and trust in a celebrity who is less admired

\section{Conclusion}

Based on the results of the two-factor analysis of variance (Two Way ANOVA), the following research results were obtained:

1. There is a difference in purchase intention based on the image of well-known and unknown brands in young girls using Instagram social media.

2. There are differences in purchase intentions based on well-known and unknown celebrity endorsements in young women using Instagram social media.

3. There is no interaction of brand image with celebrity endorsement in determining purchase intention of adolescent girls using Instagram social media. which means brand image and celebrity endorsements do not affect each other or have no effect on each other. It could be that consumers intend to buy a product because the consumer is loyal 
to a brand because of its good brand image or consumers intend to buy a product because celebrity endorsements are used as their idol figures.

\section{Reference}

Aaker, D. A. (2018). Brand equity management: Leveraging the value of a brand. Translation of Aris Ananda, Jakarta: Mitra Utama.

Adyatami, S. C., \& Krisjanti, M. (2015). The effects of celebrity endorsement on consumers' attitude towards the brand and purchasing intention. International Business Management Program, Faculty of Economics, Atma Jaya Yogyakarta University. Intention on Existing Product: A Comparative Study, Journal of Management Info, 4.

Ahmed, N., Farooq, O., \& Iqbal, J. (2014). Credibility of celebrity endorsement and buying intentions anvidence from students of Islamabad, Pakistan. International Letters of Social and Humanistic Sciences, 20(6), 1-13.

Alhaddad, A. A. (2015). The effect of advertising awareness on brand equity in social media. International Journal of e-Education, e-Business, e-Management and e-Learning, 5(2), 73

Apejoye, A. (2013). Influence of celebrity endorsement of advertisement on students' purchase intention. Journal of Mass Communication and Journalism, 3(3), 3-10.

Aronson, E., Wilson, T. D., \& Akert, R. M. (2007). Social psychology. New Jersey: Pearson Education.

Ateke, B. W., Onwujiariri, J. C., \& Nnennanya, D. A. (2015). The relationship between celebrity endorsement and brand image in the fast food industry in Port Harcourt, Nigeria. European Journal of Business and Management, 7(27), 177-186.

Balau, M. (2018). Exploring the link between intention and behavior in consumer research. EIRP Proceedings, 13.

De la Paz Toldos-Romero, M., \& Orozco-Gómez, M. M. (2015). Brand personality and purchase intention. European Business Review.

Doss, S. (2011). The transference of brand attitude: the effect on the celebrity endorser. Journal of management and marketing research, 7, 1 .

Farhangi, A. A., Abaspour, A., Bourghani Farahani, S., \& Abachian Ghasemi, R. (2014). Analyzing the impact of social media on consumer attitudes toward the brand and their intention to purchase. Global Media Journal-Persian Edition, 9(2).

Ha, N. M., \& Lam, N. H. (2017). The effects of celebrity endorsement on customer's attitude toward brand and purchase intention. International Journal of Economics and Finance, 9(1), 64-77.

Kim, D. J., Ferrin, D. L., \& Rao, H. R. (2008). A trust-based consumer decision-making model in electronic commerce: The role of trust, perceived risk, and their antecedents. Decision support systems, 44(2), 544-564.

Kotler, P., \& Armstrong, G. (2008). Marketing principles volume 2 12th edition. Jakarta: Erlangga Publisher.

Min, J. H. J., Chang, H. J. J., Jai, T. M. C., \& Ziegler, M. (2019). The effects of celebrity-brand congruence and publicity on consumer attitudes and buying behavior. Fashion and Textiles, 6(1), 1-19.

Morwitz, V. (2014). Consumers' purchase intentions and their behavior. Foundations and Trends® in Marketing, 7(3), 181-230.

Nyekwere, E. O., Kur, J. T., \& Nyekwere, O. (2013). Awareness and use of social media in advertising: The case of Facebook among residents of Port Harcourt, Nigeria. African Research Review, 7(4), 174-194.

Oladepo, O. I., \& Abimbola, O. S. (2015). The influence of brand image and promotional mix on consumer buying decision-a study of beverage consumers in Lagos State, Nigeria. British journal of marketing studies, 3(4), 97-109.

Petravičiūtè, K., einauskiené, B., Rūtelionè, A., \& Krukowski, K. (2021). Linking Luxury Brand Perceived Value, Brand Attachment, and Purchase Intention: The Role of Consumer Vanity. Sustainability, 13(12), 6912.

Preedanorawut, S., Tang, X. H., \& Nguyen, P. N. (2011). Effectiveness of Consumer Endorser in Social Media Advertisement-Impact on consumers' attitudes and behaviors. Master Thesis.

Raza, A., Karim, E., Sultan, P., \& Hasan, S. W. (2013). Effect of Branded Components on Consumer Perception of Quality and Brand Preference.

Shahid, Z., Hussain, T., \& Zafar, F. (2017). The impact of brand awareness on the consumers' purchase intention. Journal of Marketing and Consumer Research, 33(3), 34-38.

Sulu, A. C., Saerang, D. P., \& Massie, J. D. (2016). The analysis of consumer purchase intentions towards cosmetic products based on product origin. EMBA Journal: Journal of Economic Research, Management, Business and Accounting, 4(2).

Tariq, N., Imtiaz, A., \& Abbas, Q. A. (2018). Impact of celebrity endorsement on Brand Image and Customers' Purchase Intention. A Case of Pakistani Customers. SSRG International Journal of Economics Management Studies, 5(10), 25-29. 
Younus, S., Rasheed, F., \& Zia, A. (2015). Identifying the factors affecting customer purchase intention. Global Journal of Management and Business Research. Vol 15, No 2-A . 